\title{
PROBLEMY PSYCHOSPOŁECZNE RODZICÓW DZIECI ZE SPEKTRUM ZABURZEŃ AUTYSTYCZNYCH
}

\section{PSYCHOSOCIAL PROBLEMS IN PARENTS OF CHILDREN WITH AUTISM SPECTRUM DISORDERS}

\author{
Natalia Habik ${ }^{1(\mathrm{~A}, \mathrm{~B}, \mathrm{C}, \mathrm{D}, \mathrm{E}, \mathrm{F})}$, Jarosław Chmielewski ${ }^{2(\mathrm{E}, \mathrm{F})}$, Magdalena Florek-tuszczki $^{3(\mathrm{D}, \mathrm{F})}$, \\ Jerzy Zagórski ${ }^{4(\mathrm{E}, \mathrm{F})}$, Monika Szpringer ${ }^{5(\mathrm{D}, \mathrm{E})}$
}

${ }^{1}$ Wydział Lekarski i Nauk o Zdrowiu, Instytut Fizjoterapii, Uniwersytet Jana Kochanowskiego w Kielcach

${ }^{2}$ Instytut Ochrony Środowiska - Państwowy Instytut Badawczy w Warszawie

${ }^{3}$ Instytut Medycyny Wsi w Lublinie

${ }^{4}$ Wydział Nauk o Zdrowiu i Nauk Społecznych, Państwowa Szkoła Wyższa im. Papieża Jana Pawła II w Białej Podlaskiej

${ }^{5}$ Wydział Lekarski i Nauk o Zdrowiu, Instytut Zdrowia Publicznego, Uniwersytet Jana Kochanowskiego w Kielcach Habik, N., Chmielewski, J., Florek-Łuszczki, M., Zagórski, J., Szpringer, M. (2017). Problemy psychospołeczne rodziców dzieci ze spektrum zabu-
rzeń autystycznych. Rozprawy Społeczne, 11(4), 22-27. https://doi.org/10.29316/rs.2017.34

Wkład autorów:

A. Zaplanowanie badań

B. Zebranie danych

C. Dane - analiza i statystyki

D. Interpretacja danych

E. Przygotowanie artykułu

F. Wyszukiwanie i analiza

literatury

G. Zebranie funduszy

Tabele: 4

Ryciny: 0

Literatura: 20

Otrzymano: grudzień 2016

Zaakceptowano: luty 2017

\begin{abstract}
Streszczenie
Wstęp. Przedmiotem badań była analiza problemów psychospołecznych rodzin wychowujących dzieci ze spektrum zaburzeń autystycznych.

Materiał i metodyka. Badaniu poddano grupe 33 rodzin dzieci ze zdiagnozowanym spektrum autyzmu. Dzieci badanych osób uczęszczały na terapię do Krajowego Towarzystwa Autyzmu w Kielcach. Badania były przeprowadzane od maja do sierpnia 2016 roku w placówce KTA.

Wyniki. Z badań wynika, że najbardziej traumatycznym okresem związanym z występowaniem u dziecka zaburzenia jest czas oczekiwania na diagnozę do momentu jej skonstruowania. Większość badanych osób nie posiada zaspokojonych emocjonalnych i informacyjnych potrzeb, co wynika z braku wsparcia zarówno społecznego, jak i emocjonalnego.

Wnioski. Trudności z jakimi spotykają się rodzice dzieci ze spektrum autyzmu najczęściej wiążą się z trudnym dostęp do specjalistów, dużymi opłatami za prowadzoną terapię, brakiem systematycznych zabiegów, jak również zbyt dużą odległością do placówki.
\end{abstract}

Słowa kluczowe: sytuacja rodzinna, autyzm, problem psychospołeczny, niepełnosprawność intelektualna

\section{Summary}

Introduction. The main objective of the research was an analysis of psychosocial problems in families with children with autism spectrum disorders.

Material and methods. The study comprised 33 families with children diagnosed with autism spectrum. The children attended a therapy course in the National Autism Society in Kielce, where the study was carried out from May to August, 2016.

Results. The research showed that the most traumatic period associated with the appearance of the disorder in a child is the time during which the family awaits the diagnosis. Most of the respondents' emotional and informational needs are not fulfilled, which results from the lack of both social and emotional support.

Conclusion. The difficulties faced by parents of children with autism spectrum disorders most often include a difficult access to specialists, high costs of the conducted therapy, lack of systematic procedures, as well as an excessive distance to the facility where treatment is applied.

Keywords: family situation, autism, psychosocial problem, intellectual disability

\section{Wstęp}

Narodziny dziecka są bardzo ważnym momentem w życiu każdej rodziny. Matka po urodzeniu bacznie ob- serwuje zachowania noworodka w ten sposób tworzy się więź pomiędzy nią a dzieckiem. Dziecko od chwili narodzin potrzebuje opieki, ponieważ nie jest w stanie samodzielnie poradzić sobie ze zdobywaniem pożywie-

Adres korespondencyjny: Natalia Habik, Instytut Fizjoterapii, Wydział Lekarski i Nauk o Zdrowiu, Uniwersytet Jana Kochanowskiego w Kielcach, Al. IX Wieków Kielc 19, 25-317 Kielce, e-mail: habiknatalia@gmail.com; tel.: 512787539

Copyright by: Państwowa Szkoła Wyższa im. Papieża Jana Pawła II w Białej Podlaskiej, Natalia Habik, Jarosław Chmielewski, Magdalena Florek-Łuszczki, Jerzy Zagórski, Monika Szpringer

Czasopismo Open Access, wszystkie artykuły udostępniane są na mocy licencji Creative Commons Uznanie autorstwa-użycie niekomercyjne-na tych samych warunkach 4.0 Międzynarodowe (CC BY-NC-SA 4.0, http://creativecommons.org/licenses/by-nc-sa/4.0/). 
nia, utrzymaniem odpowiedniej temperatury ciała i innymi niezbędnymi do życia czynnościami. Dziecko potrzebuje matki aby przeżyć, a także by móc nawiązać pierwszą i podstawową więź społeczną. W pierwszych latach życia matka jest zazwyczaj najbliższą dziecku osobą i to ona też obserwując go staje się wrażliwą na jego zachowania, reakcje smutku i radości. Opieka nad dzieckiem przynosi jej wiele radości, spełnienia w szczególności gdy rozwój dziecka przebiega prawidłowo. W momencie kiedy matka zauważa nietypowe objawy zachowań u swojego dziecka zaczyna się niepokoić. W przypadku dzieci ze spektrum autyzmu (ASD, $\mathrm{z}$ ang. autism spectrum disorder) tymi zachowaniami może być brak reakcji na głos, unikanie kontaktu wzrokowego. Diagnoza oznacza dla całej rodziny początek trudnej drogi z autyzmem (Pisula, 2012). Wyróżnia się cztery okresy przeżyć emocjonalnych po zdiagnozowaniu u dziecka niepełnosprawności. Są to: okres szoku nazywany także okresem krytycznym, okres kryzysu emocjonalnego nazywany także okresem rozpaczy lub depresji, okres pozornego przystosowania się do nowej sytuacji oraz okres konstruktywnego przystosowania się. Przezywanie wyżej wymienionych etapów wychodzenia z kryzysu rozumiany jest jako proces zdobywania umiejętności psychicznych oraz życiowych radzenia sobie z problemami wychowania dziecka z niepełnosprawnością. Okres szoku jest najbardziej emocjonalnym etapem. Współtowarzyszy jemu występowanie wielu negatywnych oraz silnych przeżyć emocjonalnych, takich jak: rozpacz, żal, lęk, poczucie krzywdy, bezradność. Podczas jego trwania dochodzi często do zachwiania równowagi psychicznej rodziców, co może prowadzić do wadliwego sposobu funkcjonowania systemu rodzinnego (Twardowski, 2008). Pojawienie się licznych zaburzeń emocjonalnych niejednokrotnie prowadzi do zaburzeń funkcjonowania natury interpersonalnej, tj. osłabienie prawidłowych relacji między członkami rodziny (Pisula, 2007). Taki stan występuje najczęściej na skutek konfrontacji wyobrażeń rodziców $\mathrm{z}$ jego rzeczywistym stanem oraz możliwościami rozwojowymi (Wyczesany, Ucinek, 2001). Zmianie mogą ulec również wzajemne więzi między rodzicami lub rodzicami a dzieckiem zdrowym. W przypadku rodziców dziecka $\mathrm{z}$ autyzmem ich może się różnić w porównaniu do innych rodzin wychowujacych dziecko $\mathrm{z}$ niepełnosprawnością. Wynika to z faktu, że autyzm wczesnodziecięcy jest zaburzeniem rozwoju, który objawia się w ciagu trzech pierwszych lat życia. Wydłużony proces diagnostyczny, który wymaga zaistnienia pełnego spektrum autyzmu, niejako oswaja rodziców z faktem niepełnosprawności dziecka.

Autyzm jest dla rodziny bardzo dużym problemem, aczkolwiek niekoniecznie zawsze czyni on ją nieszczęśliwą. Życie z dzieckiem ze spektrum zaburzeń autystycznych często zaburza dotychczasowy układ rodziny. Charakter pojawiających się zmian zależy z jednej strony od rodzaju rozpoznania spektrum, z drugiej zaś strony od rodziny i rodzajów osobowości jej członków, tj. sposobu pokonywania trudności, samooceny, hierarchii wartości, itp. zaburzenie rozwoju dziecka zmienia nie tylko sytuację wewnątrzrodzinną, ale także oddziałuje na środowisko je otaczające (Sekułowicz, 2013). Rodzice dziecka z ASD bardzo często czuja się osamotnieni, wyobcowani, nie sa przygotowani do zmierzenia się z powstałą trudną sytuacją rodzinną, są w stanie szoku, jak również chronicznego stresu (Szabała, 2011). Największy stres występuje wówczas kiedy rodzice poszukują diagnozy. By lepiej zrozumieć sytuację rodziców wychowujących dziecko ze spektrum autyzmu oraz nature i natężenie stresu przez nich doświadczanych należy najpierw przeanalizować przyczyny występowania trudności w adaptacji rodziców do zastałej trudnej sytuacji życiowej. Rodzice dziecka z autyzmem potrzebują rozmowy ze specjalistami, którzy wyjaśnią im, że dziecko może odtrącać nawiązywanie bliskości $\mathrm{z}$ nimi $\mathrm{z}$ powodu konstytucjonalnej podatności. Co jest u dziecka spowodowane postawą obronną na jakość i natężenie poszczególnych bodźców zmysłowych wysyłanych przez rodziców, a nie na nich samych (Olechnowicz, Wiktorowicz, 2012). Dla rodziców największą trudnością w wychowaniu dziecka ze spektrum autyzmu stanowi brak komunikacji. Niestety intuicyjne postępowanie skuteczne wobec dziecka zdrowego jest niewystarczające w przypadku dziecka z zaburzeniami ze spektrum autyzmu, a nawet czasami może przynieść skutek odwrotny. Do najważniejszych zmiennych determinujących sytuację rodziców zalicza się: płeć, wiek, poziom wykształcenia, aktywność zawodową, temperament, osobowość oraz poczucie kompetencji rodzicielskich (Randall, 2010). Wśród dzieci tymi determinantami są wiek, stopień natężenia występującego zaburzenia, zdolność do adaptacji otoczenia. Natomiast do czynników środowiskowych zalicza się wsparcie społeczne, stosunek otoczenia do dziecka, status socjoekonomiczny rodziny.

\section{Materiał i metody badań}

Badaną grupę stanowiły 33 rodziny dzieci ze zdiagnozowanymi całościowymi zaburzeniami rozwojowymi ze spektrum autyzmu. Dzieci badanych rodzin uczęszczały na zajęcia terapeutyczno-rehabilitacyjne do placówki Krajowego Towarzystwa Autyzmu w Kielcach. Badania przeprowadzono w oparciu o obserwację, której zadaniem było zebranie spostrzeżeń dotyczacych wysteppowania problemów psychospołecznych rodziców dzieci ze spektrum autyzmu oraz metodę sondażu diagnostycznego $\mathrm{w}$ tym technikę ankietowania. W tym celu wykorzystano narzędzie badawczeautorski kwestionariusz ankiety dotyczący danych metryczkowych stanowiących kryteria włączenia do badań, tj. wychowywanie dziecka ze spektrum autyzmu oraz uczęszczanie na terapię do Krajowego Towarzystwa Autyzmu w Kielcach. Pytania z kwestionariusza ankiety zawierały informacje dotyczące sytuacji rodzin wychowujących dziecko $\mathrm{z}$ autyzmem w kontekście problemów psychospołecznych oraz sytuacji socjoekonomicznej rodzin, tj. struktury liczbowej, sytuacji materialnej, rezygnacji z pracy członków rodziny na rzecz wychowania dziecka z autyzmem. Badania odbywały się w okresie od maja do sierpnia 2016 roku. W bada- 
niach przyjęto następujące założenia, stanowiące hipotezę główną: W rodzinach wychowujących dziecko $\mathrm{z}$ autyzmem występują problemy psychospołeczne. Przeprowadzone badania własne uzupełniają wiedzę na temat funkcjonowania rodzin $\mathrm{z}$ dzieckiem $\mathrm{z}$ zaburzeniami ze spektrum autyzmu i trudności związanych $\mathrm{z}$ wychowaniem takiego dziecka. Zebrany materiał uzyskany z badań poddano analizie statystycznej przy użyciu programu Statistica, przyjmując za istotne statystycznie różnice na poziomie $\mathrm{p}<0,05$.

\section{Wyniki}

Grupę badanych stanowili rodzice dzieci ze zdiagnozowanym autyzmem w wieku od 25 do 53 roku życia. Średnia wieku badanych to $36 \pm 5$,6 lat. Wśród badanych najwięcej posiadało wykształcenie wyższe, tj. 22 osoby $(67 \%)$, średnie 9 osób (27\%) i podstawowe tylko 2 osoby (6\%). W badanej grupie rodzin badano ile dzieci wchodzi w jej skład. Okazało się, że 21 rodzin (61\%) wychowuje tylko jedno dziecko, w 11 rodzinach (33\%) jest 2-3 dzieci, a tylko u 2 (6\%)badanych rodzin występuje powyżej 4 dzieci.

W badaniach analizowano liczbę osób z najbliższego kręgu rodzinnego mieszkających we wspólnym gospodarstwie domowym wraz z dzieckiem ze spektrum autyzmu (tabela 1).

Tabela 1. Struktura liczbowa osób mieszkających z dzieckiem $\mathrm{z}$ autyzmem

\begin{tabular}{|c|c|c|c|c|c|c|c|c|c|}
\hline \multicolumn{2}{|c|}{ Matka } & \multicolumn{2}{|c|}{ Ojciec } & \multicolumn{2}{c|}{$\begin{array}{c}\text { Rodzeń- } \\
\text { stwo }\end{array}$} & \multicolumn{2}{c|}{ Babcia } & \multicolumn{2}{c|}{ Dziadek } \\
\hline $\mathrm{N}$ & $\%$ & $\mathrm{~N}$ & $\%$ & $\mathrm{~N}$ & $\%$ & $\mathrm{~N}$ & $\%$ & $\mathrm{~N}$ & $\%$ \\
\hline 30 & 91 & 26 & 79 & 13 & 40 & 18 & 55 & 15 & 46 \\
\hline
\end{tabular}

Źródło: opracowanie własne.

Zapytano również o konieczność rezygnacji z pracy przez rodziców dziecka z zaburzeniami ze spektrum autyzmu. Z uzyskanych danych wynika, że w 20 rodzinach $(60 \%)$ z pracy musiał zrezygnować jeden z rodziców, w 9 (28\%) rezygnacja z pracy nastąpiła przez pewien jedynie okres czasu, natomiast w 4 rodzinach $(12 \%)$ żaden z rodziców nie zrezygnował z pracy zawodowej (por. tabela 2).

Tabela 2. Struktura liczbowa rezygnacji z pracy wśród rodziców dzieci z autyzmem

\begin{tabular}{|c|c|c|c|c|c|}
\hline $\begin{array}{c}\text { Rezygnacja na } \\
\text { stałe przez 1 } \\
\text { rodzica }\end{array}$ & \multicolumn{2}{|c|}{$\begin{array}{c}\text { Rezygnacja przez } \\
\text { pewien okres } \\
\text { przez 1 rodzica }\end{array}$} & \multicolumn{2}{|c|}{ Brak rezygnacji } \\
\hline $\mathrm{N}$ & $\%$ & $\mathrm{~N}$ & $\%$ & $\mathrm{~N}$ & $\%$ \\
\hline 20 & 60 & 9 & 28 & 4 & 12 \\
\hline
\end{tabular}

Źródło: opracowanie własne.

Wraz z rezygnacją z pracy jednego z rodziców dochodzi do pogorszenia sytuacji materialnej rodziny. Wśród badanych rodzin najczęściej pojawiająca się kwota przypadająca na utrzymanie jednego członka rodziny to 460-900 zł $(n=15,45 \%)$. W grupie 6 rodzin (19\%) egzystencja obejmowała kwotę 340460 zł. Wśród grupy rodzin o nieco wyższym niż przeciętnym dochodzie, tj. 900-1500 zł znalazło się 11 rodzin (36\%). W badaniach poddano również analizie sytuację materialną rodzin wychowujących dziecko z autyzmem. Z badań wynika, że znaczna część badanych rodzin (45\%) określiła swoją sytuację materialną jako „przeciętną”, jedynie co czwarty badany określił ją jako dobrą (25\%). Średni koszt opieki nad dzieckiem z zaburzeniami całościowymi ze spektrum autyzmu wyniósł około 934 zł. Minimalny koszt utrzymania dziecka w badanych rodzinach to 220 zł. Z analizy przeprowadzonych badań wynika, że posiadanie dziecka z ASD w rodzinie nie wpływa istotnie na kwotę przypadającą na utrzymanie jednego członka rodziny $(\mathrm{p}=0,0991)$.

Podczas planowania terapii dziecka z zaburzeniami ze spektrum autyzmu ważne jest pozostanie dzieci we wspólnym gospodarstwie domowym w rodzinie. W badaniach wykazano istotną zależność pomiędzy występowaniem typu więzi rodzinnych a sytuacją materialną badanych rodzin. Z przeprowadzonych badań wynika, że u 6 (46\%) rodzin jednopokoleniowych występuje sytuacja materialna określona na poziomie przeciętnym. Natomiast w przypadku 9 $(45 \%)$ rodzin wielopokoleniowych większość badanych oceniła swoją sytuację ekonomiczną na poziomie bardzo dobrym (por. tabela 3).

Tabela 3. Struktura liczbowa zależności pomiędzy typem rodziny a sytuacją materialną

\begin{tabular}{|c|c|c|c|c|c|c|c|c|}
\hline $\begin{array}{c}\text { typ rodziny/ } \\
\text { sytuacja } \\
\text { materialna }\end{array}$ & \multicolumn{2}{|c|}{$\begin{array}{c}\text { bardzo } \\
\text { dobra }\end{array}$} & \multicolumn{2}{|c|}{ dobra } & $\begin{array}{r}\text { przecięt- } \\
\text { na }\end{array}$ & \multicolumn{2}{|c|}{ zła } \\
\hline $\begin{array}{l}\text { rodzina jedno- } \\
\text { pokoleniowa }\end{array}$ & 1 & $8 \%$ & 3 & $23 \%$ & 6 & $46 \%$ & 3 & $23 \%$ \\
\hline $\begin{array}{l}\text { rodzina wielo- } \\
\text { pokoleniowa }\end{array}$ & 9 & $45 \%$ & 6 & $30 \%$ & 3 & $15 \%$ & 2 & $10 \%$ \\
\hline
\end{tabular}

Źródło: opracowanie własne.

Z analizy wyników prowadzonych badań wynika, że znaczące miejsce wśród problemów występujących $\mathrm{w}$ rodzinie $\mathrm{z}$ dzieckiem ze spektrum autyzmu stanowi brak posiadania przez rodziców własnego samochodu. Bardzo dużym problemem dla rodziców jest również odległość pomiędzy miejscem zamieszkania a poradnią. Z przeprowadzonych badań wynika, że co 4 badana osoba korzysta jedynie z komunikacji miejskiej. Natomiast średnia odległość pomiędzy miejscem zamieszkania a ośrodkiem terapeutyczno-wychowawczym wynosi około 36 kilometrów

Opieka i troska rodziców wobec dziecka ze zdiagnozowanym spektrum autyzmu wiąże się z występowaniem wielu problemów. Mogą one przyjmować różnorodny charakter i pojawiać się w wielu strefach życia rodzin, jednakże zawsze dotykają one sfery emocjonalnej matki. Z analizy danych wynika, że 
wśród badanych najwięcej rodzin $(n=17,52 \%)$ oceniło poziom obciążenia psychicznego na poziomie średnim. Tylko 2 rodziny (6\%) określa odczuwane obciążone jako bardzo silne $\mathrm{p}=0,0165$. Szczegółowe wyniki przedstawiono $\mathrm{w}$ tabeli 4 .

Tabela 4. Struktura liczbowa obciążenia psychicznego wśród badanych rodzin

\begin{tabular}{|c|c|c|c|c|c|c|c|c|c|}
\hline \multicolumn{2}{|c|}{$\begin{array}{c}\text { obciążenie } \\
\text { bardzo } \\
\text { silne }\end{array}$} & \multicolumn{2}{|c|}{$\begin{array}{c}\text { obciążenie } \\
\text { silne }\end{array}$} & \multicolumn{2}{|c|}{$\begin{array}{c}\text { obciążenie } \\
\text { średnie }\end{array}$} & \multicolumn{2}{|c|}{$\begin{array}{c}\text { obciąże- } \\
\text { nie w nie- } \\
\text { wielkim } \\
\text { stopniu }\end{array}$} & \multicolumn{2}{|c|}{$\begin{array}{c}\text { brak } \\
\text { obciąże- } \\
\text { nia }\end{array}$} \\
\hline $\mathrm{N}$ & $\%$ & $\mathrm{~N}$ & $\%$ & $\mathrm{~N}$ & $\%$ & $\mathrm{~N}$ & $\%$ & $\mathrm{~N}$ & $\%$ \\
\hline 2 & 6 & 4 & 12 & 17 & 52 & 8 & 24 & 2 & 6 \\
\hline
\end{tabular}

Źródło: opracowanie własne.

W badaniach analizowano również poziom poczucia winy i bezradności wśród rodzin wychowujących dziecko z całościowymi zaburzeniami rozwojowymi ze spektrum autyzmu. U 26 (78\%) badanych rodzin wystąpiło lub też występuje poczucie winy. Natomiast odczuwanie bezradności wobec wychowania dziecka z ASD zgłosiło 23 (70\%) badanych rodzin.

\section{Dyskusja}

Występowanie w rodzinie dziecka z zaburzenia ze spektrum autyzmu przysparza rodzicom wiele problemów zarówno emocjonalnych, wychowawczych jak i społecznych. Bardzo często prowadzi do zakłócenia funkcjonowania rodziny prowadząc do jej rozpadu. Najczęściej opiekę nad dzieckiem z autyzmem sprawują matki, dlatego też większość autorów dokonując analizy badań skupia się jedynie na ich doświadczeniach. W najbliższym otoczeniu rodzinnym badanych osób, które dzieliły wspólne mieszkanie $\mathrm{z}$ dzieckiem z autyzmem byli rodzice, rodzeństwo i dziadkowie. Występowanie więzi emocjonalnych w relacjach dziadków z dzieckiem znacząco wpływa na przebieg jego wychowania. Mikołajczyk- Lerman (2011) w swoich badaniach potwierdza, że w 80\% badanych rodzin, matki poświęcają najwięcej czasu na wychowanie swojego dziecka. Natomiast jedynie w $21 \%$ przypadków rodzin, ojciec włącza się w opiekę nad dzieckiem. Aby dokonać diagnozy występowania więzi emocjonalno- społecznej w rodzinach dzieci z ASD, autorka podkreśliła znaczący fakt wychowania dzieci w większości przypadków (65\%) przez rodziny pełne, tj. z obojgiem rodziców. Jednakże w 13,2 \% rodzin ojciec odszedł, po pojawieniu się diagnozy.

Wychowywanie dziecka z całościowymi zaburzeniami rozwojowymi ze spektrum autyzmu ma znaczący wpływ na pogorszenie sytuacji bytowej całej rodziny. Najczęściej jedna osoba z badanych rodzin musi zrezygnować z pracy zawodowej, by móc w pełni zająć się wychowywaniem dziecka, co w efekcie wpływa na obniżenie dochodów pieniężnych rodziny. Najczęściej z pracy muszą zrezygnować matki. Rodziny przebywające we wspólnym gospodarstwie domowym mają bardzo duży wpływ na sytuację materialną. Według przeprowadzonych badań, rodziny wielopokoleniowe mają lepszy poziom materialnej egzystencji niż rodziny jednopokoleniowe. Uzyskane wyniki badań własnych są bardzo podobne do badań prowadzonych przez Karwowską (2008) oceniającą aspekty środowiska rodzinnego w 63 rodzinach. Według autorki w ponad połowie badanych rodzin sytuacja finansowa rodzin wychowujących dziecko z niepełnosprawnością jest zaledwie dostateczna. Według Mikołajczyk-Lerman (2011) największymi problemami $\mathrm{z}$ jakimi spotykają się rodziny wychowujące dzieci z niepełnosprawnością jest brak środków materialnych na poważne wydatki- 57,6\%, problemy edukacyjne niepełnosprawnego dziecka $-35,7 \%$, złe warunki mieszkaniowe $-24 \%$ i brak pieniędzy umożliwiający codzienne funkcjonowanie $-23,9 \%$. W opinii Cavallo i wsp. (2009) badania wskazują wyraźnie na występowanie związku pomiędzy czynnikami społeczno- demograficznym a potrzebami wsparcia rodziny. Większego wsparcia społecznego według wyników przeprowadzonych badań wymagały matki z niższym stopniem wykształcenia, rodzice aktywni zawodowo i pełne rodziny. Według analizy badań własnych ankietowani rodzice za największą przeszkodę w funkcjonowaniu rodziny z dzieckiem ze spektrum zaburzeń autystycznych wskazywali trudną sytuację finansową, która nie jest w stanie w pełni zabezpieczyć koszty edukacyjno-rehabilitacyjne.

Postępowanie terapeutyczne dziecka z niepełnosprawnością często zajmuje większość czasu życia rodziny. Uczęszczanie na terapię ma w głównej mierze na celu zwiększenie szans dziecka na uzyskanie samodzielności. Wielu terapeutów twierdzi, że rodzice powinni brać czynny udział w terapii swojego dziecka (Kornaś, 2010). Trudności z jakimi borykają się rodzice dzieci z całościowymi zaburzeniami rozwojowymi ze spektrum autyzmu w zakresie podejmowanych działań terapeutyczno- rehabilitacyjnych najczęściej wiążą się z trudnym dostęp do specjalistów, dużymi kosztami za prowadzoną terapię, brakiem systematycznych zabiegów, brakiem posiadania własnego środka transportu, jak również zbyt dużą odległością do placówki/ ośrodka. Podobne wyniki w tym kontekście badań otrzymała Jackson (2014). Autorka badała 20 rodziców wychowujących dzieci z poważnymi zaburzeniami rozwojowymi, przebywających w ośrodku poza pierwotnym miejscem zamieszkania. Z analizy badań okazało się, ze badani rodzice odczuwają bardzo często negatywne emocje, tj. poczucie winy, smutku, strachu, gniewu lub poczucie ulgi wobec zaistniałej sytuacji. Singhi i wsp. (1990) analizowali problemy rodziców posiadających dziecko z niepełnosprawnością fizyczną, intelektualną korelując je z grupą kontrolną, tj. dziećmi zdrowymi. Z przeprowadzonych badań wynikało, że rodziny wychowujące dzieci $\mathrm{z}$ niepełnosprawnością 
najczęściej wskazywali na występujące problemy dotyczące sytuacji materialnej, brakiem odpoczynku, ograniczeniem interakcji społecznych z innymi ludźmi. Uzyskane ogólne wyniki obciążenia społecznego były istotnie wyższe u rodzin wychowujących dziecko $\mathrm{z}$ niepełnosprawnością $\mathrm{w}$ porównaniu do grupy kontrolnej. Parkinson zajmował się w swoich badaniach znaczeniem kontaktów społecznych w rozwoju dzieci z niepełnosprawnością. Analizy uzyskanych wyników autor dokonał w oparciu o grupę 28 dzieci i 35 rodziców. Z otrzymanych wyników można było stwierdzić, że częściej nacisk na kontakty społeczne kładą rodzice, podczas gdy dzieci zadawała czas wolny spędzany w samotności. Charakter i poziom stresu występujący wśród rodziców mogą potęgować stopień zaburzenia dziecka. Dodatkową pojawiającą się trudnością jest konieczność sprawowania długotrwałej, a często nawet całodobowej opieki nad dzieckiem, która wraz z wiekiem może wzrastać. Problemem, który występuje wśród opinii rodziców jest dostosowanie odpowiedniej terapii i metody wychowania, dostęp do usług opieki terapeutyczno- rehabilitacyjnej (Parkinson, 2011). Według badań Fernandez-Alcantara (2011) przeprowadzonych w grupie 24 hiszpańskich rodziców, najtrudniejszym etapem w radzeniu sobie z negatywnymi emocjami dotyczącymi perspektywy posiadania idealnego, zdrowego dziecka jest moment uzyskania diagnozy występującego zaburzenia i stopień jej ciężkości. Badanie to również potwierdza Karwowska (2008), która analizowała emocje rodziców dzieci z niepełnosprawnością intelektualną. Według przeprowadzonych przez autorkę badań okazało się, że najbardziej traumatycznym okresem związanym $\mathrm{z}$ występowaniem u dziecka zaburzenia był czas od oczekiwania na diagnozę do momentu jej postawienia. Podczas tego okresu większość badanych osób nie miała zaspokojonych emocjonalnych i informacyjnych potrzeb, co wynikało z braku wsparcia zarówno społecznego jak i emocjonalnego. Znaczący wkład w rozumienie sytuacji rodzin dzieci niepełnosprawnych poddanych różnym formom postępowania terapeutyczno-rehabilitacyjnego wnoszą badania przeprowadzone przez Kruijsen-Terpstra i wsp. (2014). Powyżej wymienieni autorzy w oparciu o przegląd prac zaobserwowali, że rodzice posiadają różne potrzeby w trakcie przebiegu terapii swojego dziecka, jak też potrzebują czasu by móc zbudować relację $\mathrm{z}$ terapeutami swoich dzieci.

Problemy $\mathrm{z}$ jakimi borykają się rodzice dzieci $\mathrm{z}$ występującymi zaburzeniami prowadzą do pojawienia się stresu, który warunkuje zmiany w ich zachowaniu. Człowiek w sytuacjach stresogennych ma własny, przez siebie opracowany sposób reagowania. Rodzice najczęściej radzą sobie ze stresem poprzez wsparcie, które otrzymują od najbliższej rodziny. Niektórzy rodzice również reagują na stres unikając go lub skupiając swoja uwagę na czynnościach zastępczych. Według badań prowadzonych przez Thabet (2014) u rodziców dzieci z niepełnosprawnością chroniczny poziom lęku występował u $68 \%$ badanych, a depresja u $52 \%$ osób i przeważał on głównie u matek i wiązał się z ich niskim statutem socjoekonomicznym. Zakres strategii radzenia sobie ze stresem rodziców skupiających się na emocjach występował u $68 \%$ spośród nich, na pokonywaniu trudności u 32\%. Istnieje opinia, według, której postrzeganie rodzin dzieci z występującą niepełnosprawnością może pogarszać sytuacja niedużych społeczności, jak w przypadku Latynosów, u których istnieją trudności w diagnozowaniu i leczeniu dziecka ze spektrum autyzmu. Przyczyną tego jest bardzo duży odsetek ubóstwa, brak równouprawnień w korzystaniu z usług, jak i ograniczona znajomość języka angielskiego. W wielu państwach rodzice dzieci niepełnosprawnych w dalszym ciągu są napiętnowani i wykluczeni społecznie.

Podsumowując, wychowanie dziecka z całościowymi zaburzeniami rozwojowymi ze spektrum autyzmu wpływa na funkcjonowanie każdej rodziny bez wyjątku. Działanie rodziców w głównej mierze opiera się na zaspokojeniu wszelkich potrzeb dziecka oraz zapewnieniu odpowiedniej opieki terapeutyczno- rewalidacyjnej. Badania Piskur (2014) prowadzone w grupie 146 rodziców dzieci z niepełnosprawnością ewidentnie wskazują na występowanie wyraźnych deficytów w zakresie wiedzy na temat rozwiązań ustawowych i wykonawczych.

\section{Literatura:}

1. Cavallo, S., Feldman, E., Swaine, B. (2009). Is parental coping associated with the level of function in children with physical disabilities? Child Care Health Dev, 35, 33-40.

2. Bourke-Taylor, H. (2013). Relationships between sleep disruptions health and care responsibilities among mothers of school- aged children with disabilities. J. Paediatr Child Health, 49, 775-782.

3. Fernandez- Alcantara, M. (2015). Feelings of loss in parents of children with infantile cerebral palsy. Disability Health J, 8, 93-101.

4. Jackson, J. (2014). Parental adaptation to out- of- home placement of a child with serve or profound developmental disabilities. Am J Intellect Dev Disabil, 119, 203-219.

5. Karwowska, M. (2008). Zmaganie się z problemami dnia codziennego rodziców wychowujących dziecko z niepełnosprawnościq umysłowq. Bydgoszcz: Wydawnictwo KPSW.

6. Kornaś, D. (2010). Doświadczenia rodziców dzieci niepełnosprawnych intelektualnie w procesie wczesnej interwencji, W: A. Klinik (red.), Osobliwości zabiegów terapeutycznych w otwartym środowisku społecznym (s. 13-19). Kraków: Wydawnictwo Impuls. 
7. Kruijsen-Terpstra, A., Katelaar, M., Boeije, H. (2014). Parent`s experience with physical and occupational therapy for their young child with cerebral palsy: a mixed studied review. Child Care Health Dev, 40, 787796.

8. Mikołajczyk-Lerman, G. (2011). Kobiety i ich niepełnosprawne dzieci. Acta Universitatis Lodziensis, 39, 73-90.

9. Olechnowicz, H., Wiktorowicz, R. (2012). Dziecko z autyzmem. Wyzwalanie potencjału rozwojowego. Warszawa: Wydawnictwo Naukowe PWN.

10. Parkinson, K. (2011). Incorporating children`s and their parents` perspectives into conditio-specific quality - of- life instruments for children with cerebral palsy. Value Health, 14, 705-711.

11. Piskur, B. (2015). What do parents need to enhance participation of their school- aged child with a physical disability? Child Care Health Dev, 41, 84-92.

12. Pisula, E. (2012). Rodzice dzieci z autyzmem. Warszawa: Wydawnictwo Naukowe PWN.

13. Pisula, E. (2007). Rodzice i rodzeństwo dzieci z zaburzeniami rozwoju. Warszawa: Wydawnictwo Uniwersytetu Warszawskiego.

14. Randall, P. (2010). Autyzm. Jak pomóc rodzinie. Sopot: Gdańskie Wydawnictwo Psychologiczne.

15. Sekułowicz, M. (2013). Wypalenie się sił rodziców dzieci z niepełnosprawnością. Wrocław: Wydawnictwo Naukowe Dolnośląskiej Szkoły Wyższej.

16. Singhi, P., Goyal, D., Pershad, S. (1990). Psychosocial problems in families of disabled children. Br J. Med. Psychol, 63, 173-182.

17. Szabała, B. (2011). Wsparcie społeczne matek dzieci niepełnosprawnych. Człowiek- NiepełnosprawnośćSpołeczeństwo, 1(13), 47-67.

18. Thabet, B. (2014). Psycho- emotional impact of a child`s disability on parents. Archives de Pediatr, 14, 301-308.

19. Twardowski, A. (2008). Sytuacja rodzin dzieci niepełnosprawnych. W: I. Obuchowska (red.), Dziecko niepełnosprawne $w$ rodzinie (s. 212-253). Warszawa: Wydawnictwo WSiP.

20. Wyczesany, J., Ucinek, A. (2001), Wybrane aspekty funkcjonowania rodzeństwa dzieci autystycznych. W: T. Gałkowski, J. Kossewska (red.), Autyzm wyzwaniem naszych czasów (s. 174-186). Kraków: Wydawnictwo Naukowe Akademii Pedagogicznej. 